\title{
DNA Damage During Seed Ageing
}

\author{
Radha, B. $\mathrm{N}^{1}$.,Channakeshava, B. C ${ }^{1}$., K. Bhanuprakash ${ }^{2}$, \\ K. T. Pandurange Gowda ${ }^{3}$ B. K. Ramachandrappa ${ }^{4}$ and R. Munirajappa ${ }^{5}$ \\ ${ }^{a}$ University of Agricultural Sciences, GKVK, Bangalore-560065, Karnataka, India ${ }^{b}$ Present address: College of \\ Sericulture, Chinthamani-563125, Kolar, Karnataka, India
}

\begin{abstract}
Seed ageing is influenced by two environmental factors, $R H$ and temperature. The deterioration of the stored seed is a natural phenomenon and the seeds tend to lose viability even under ideal storage conditions. Accelerated ageing has been recognized as a good predictor of the storability of seed lots. Aged seeds show decreased vigour and produce weak seedlings that are unable to survive once reintroduced into a habitat. Vigour testing becomes more important in seeds stored under unknown or adverse storage conditions. In seed ageing damage to cellular membranes, decrease in mitochondrial dehydrogenases activities and DNA degradation increases.
\end{abstract}

Key words: Maize, accelerated ageing, vigour, dehydrogenases, DNA integrity

\section{Introduction}

The main external factors causing seed damage during storage are the temperature, relative air humidity and oxygen. Possibility to regulate these factors makes the basis for longer seed storage. Seed deterioration can be defined as "deteriorative changes occurring with time that increase the seed's vulnerability to external challenges and decrease the ability of the seed to survive." It is an undesirable attribute of agriculture. Annual losses of revenue from seed products due to deterioration can be as much as $25 \%$ of the harvested crop. This value would be in the billions of U.S. dollars. An understanding of seed deterioration, therefore, provides a template for improved crop production as well as increasing agricultural profits.The most widely accepted single criterion of seed deterioration is reduced germinability. However, many tests for measuring the loss in vigor have been developed based on the physiological effect of ageing (ISTA, 1993; Tekrony, 1993; Woltz and Tekrony, 2001; Jatoi et al., 2004; Khan et al., 2007; Malik and Shamet, 2009). Among them the most important method is accelerated ageing which is done by subjecting seeds to elevated temperature and high relative humidity moisture content. It provides a simple and good method for studying sequence and relationship of process of deterioration with respect to storage atmosphere (temperature, relative humidity and moisture) over short periods.

Many hypotheses have been proposed regarding causes of seed ageing such as loss of vigour and viability in terms of germination due to many physiological changes in deteriorated seeds. However the exact molecular changes involved in seed deterioration have not been very well studied in order to support the above hypothesis.DNA and RNA orchestrate gene activity implicated in life and cell death processes (Bushell et al., 2004; Hoeberichts and Woltering 2003). It is therefore surprising that the integrity of nucleic acids during seed ageing has received relatively little attention in the recent literature. Changes in nucleic acid content (Brockelhurst and Fraser 1980; Sen and Osborne 1974, 1977; Thompson et al. 1987) and more recently, DNA fragmentation (Kranner et al., 2006; Osborne 2000), have been reported in seeds in relation to maturation and germination rate. Single and double strand breaks of DNA accumulate in ageing seeds (Tuteja et al., 2001) and DNA fragmentation was correlated with seed death induced by drying in 'recalcitrant', i.e. desiccation intolerant, seeds (Faria et al., 2005; Kranner et al., 2006). It was therefore, thought imperative to investigate the molecular changes to apprehend the apparatus of seed deterioration in accelerated ageing.

\section{Materials And Methods}

\section{Seed moisture content $(\%)$}

Moisture content of seed sample was determined by gravimetric method by using high constant temperature oven method as per ISTA (2010).

\section{Germination (\%)}

One hundred seeds in three replicates were drawn at random from each treatment and the standard germination test was conducted in the laboratory using 'between paper' method as per ISTA (2010). Hundred seeds each of three replications were placed equidistantly on moist germination paper. The rolled towels were incubated in germination chamber maintained at $25 \pm 1^{\circ} \mathrm{C}$ and 90 per cent relative humidity (RH). The final 
counts were taken on 7 th day of germination test. The percentage of germination was expressed based on the normal seedlings.

\section{Electrolyte leakage $\left(\mathrm{dSm}^{-1}\right)$}

The electrolyte leakage of seed was determined as per procedure outlined by ISTA (2010). Twenty five seeds were taken randomly in three replications and soaked in $50 \mathrm{ml}$ of distilled water for 18 hours at $25 \pm 1^{0} \mathrm{C}$. After incubation, the seed leachate was decanted and the electrolyte leakage was measured by Digital Conductivity Meter (Model-D1 9009) and expressed in dSm-1.

\section{Total dehydrogenase activity $\left(\mathrm{OD} @ \mathrm{~A}_{480} \mathrm{~nm}\right)$}

The total dehydrogenase activity of the seeds was estimated as per the method described by Perl et al. (1978). Ten seeds of three replications selected randomly were pre-conditioned by soaking in water for 24 hours. Then ten pre imbibed seeds were randomly selected in each sample, seed was cut longitudinally and soaked in 0.5 per cent Tetrazolium Chloride solution in a test tube and incubated at $25 \pm 1{ }^{\circ} \mathrm{C}$ under dark for six hours. Then they were washed thoroughly with distilled water, the red colouredformazan from the stained embryos was extracted by soaking these embryos with $5 \mathrm{ml}$ of 2-methoxy ethanol for 6-8 hours in an airtight container. The extract was decanted and the colour intensity was measured in Spectrophotometer (Model Mini Spec 17) at $480 \mathrm{~nm}$ with suitable blank (Methoxy ethanol). The total dehydrogenase activity (TDH) was expressed in Absorbance.

\section{DNA extraction and analysis}

DNA was extracted from aged maize seeds as per the CTAB (CetylTrimethyl Ammonium Bromide) method of Doyle and Doyle (1990) with slight modifications. Aged maize seeds were ground into fine powder with liquid nitrogen by using pestle and mortar and homogenized completely by adding $800 \mu 1$ of 2 per cent of CTAB extraction buffer. While grinding a pinch of PVP was added. Homogenized solution was transferred into centrifuge tubes and kept in water bath for about one hour at $65^{\circ} \mathrm{C}$. To this equal volume of wet chloroform was added and tilted slowly and centrifuge at $8000 \mathrm{rpm}$ for $15 \mathrm{~min}$. Three layers were formed; bottom layer was chloroform, middle layer was seed tissue and top layer was aqueous buffer layer. Pipette out aqueous layer into another centrifuge tube and add equal volume of wet chloroform.Centrifuge at $6000 \mathrm{rpm}$ for $15 \mathrm{~min}$. and take out the supernatant, repeat the wet chloroform wash for 2 times. To the supernatant $500 \mu \mathrm{l}$ of chilled isopropanol was added and refrigerated for overnight. Centrifuge at $5000 \mathrm{rpm}$ for $10 \mathrm{~min}$. at $4^{\circ} \mathrm{C}$, pour out the isopropanol and the precipitated DNA pellet was air-dried. DNA pellet was dissolved in $50 \mu \mathrm{TE}$ buffer. RNase was added and incubated for $30 \mathrm{~min}$. at $37^{\circ} \mathrm{C}$.

\section{DNA integrity}

DNA integrity was checked on $0.8 \%$ agarose gel. Prepare $0.8 \%$ of agarose gel by dissolving 0.8 gram in $100 \mathrm{ml}$ of $1 \mathrm{X}$ TBE buffer.

Quantification of DNA by spectrophotometric method

The DNA was quantified by measuring diluted seed sample in TE buffer at A260 nm value using a spectrophotometer. The formula used for quantification was:

$$
\text { DNA }(\mathrm{ng} / \mathrm{g} \text { of seed })=50 \mathrm{ng} / \mathrm{ml} \times \text { OD value } @ \text { A260nm } \times \text { dilution factor }
$$

\section{Statistical analysis}

Data of germination percentage were subjected to data transformation (acrsine) before the statistical analysis in order to unify the variance of the data. Data statistically analyzed as per the methods outlined by Sundararaj et al. (1972) adopting "Fisher's Analysis of Variance Techniques". Critical difference (CD) values were computed at 5 and 1 per cent level wherever ' $F$ ' test was significant.

\section{Moisture content}

\section{Results}

With respect to accelerated ageing, the seed moisture was lower $(13.12 \%)$ in $40^{\circ} \mathrm{C}(\mathrm{T} 1)$ and higher in $42^{\circ} \mathrm{C}$ (T2), among relative humidity levels it was higher (13.22\%) in 100 per cent and lower (12.84\%) in 85 per cent (Fig 5.11). Among accelerated ageing periods twelve day of ageing was recorded higher (13.64\%) moisture content and it lower $(12.77 \%)$ in three day aged and unaged $(12.19 \%)$.

\section{Germination}

Ageing showed significant differences in normal seedling in terms of germination percentage, abnormal seedlings, fresh ungerminated seeds and dead seeds at final count of germination in accelerated ageing (Table 1). Storage of maize seeds at an elevated temperature and humidity has a profound effect upon ability to 
germinate. Change in germination percentage of maize seeds exposed to accelerating ageing condition is shown in (Fig. 1).During storage at elevated temperatures and low humidity the water content of the seed declines from an initial $97 \%$ to $2.7 \%$ in case of accelerated ageing by day 12 . The interaction between relative humidity levels and ageing period differed significantly for FUG seeds over the unaged. Highest (4.50\%) FUG seeds were recorded in three days of ageing at $42^{\circ} \mathrm{C}$ and $100 \%(3.00 \%)$.

All three factors viz., temperature, relative humidity and ageing period playan important role in decreased germination percentage by increasing dead seed percentage. When maize seeds exposed elevated temperatures $(33.53 \%)$, relative humidity $(33.47 \%)$ and ageing periods $(81.46 \%)$ dead seeds percentage was increased (Table 1).

\section{Electrolyte leakage}

Before ageing, the initial value of seed electrolyte leakage was approximately $0.106 \mathrm{dSm}^{-1}$ (Fig. 2). Seed ageing at $42^{\circ} \mathrm{C}$ and $100 \% \mathrm{RH}$ resulted in a progressive increase in electrolyte leakage from 0.106 to 0.639 $\mathrm{dSm}^{-1}$ over 12 days of treatment.

\section{Total dehydrogenase activity}

The interaction of temperatures, relative humidity levels and ageing period differed significantly for TDH activity over the unaged (Fig. 2). Highest (0.670) TDH activity was observed in three day aged seed, whereas least was observed in twelve day aged seeds $(0.031)$ at $42^{\circ} \mathrm{C}$ and $100 \% \mathrm{RH}$.

\section{DNA content}

Unaged seeds had shown $60 \mathrm{ng} \mathrm{g}^{-1}$ of DNA content. Accelerated ageing had significant effect on DNA content (Fig. 2). Highest (54 $\mathrm{ng} \mathrm{g}^{-1}$ ) DNA content was observed in three day aged seed, whereas least was observed in twelve day aged seeds $\left(1 \mathrm{ng} \mathrm{g}^{-1}\right)$ at $42^{0} \mathrm{C}$ and $100 \% \mathrm{RH}$.

\section{DNA integrity}

A hallmark of ageing is the organized loss in DNA integrity when resolved by agarose gel electrophoresis (Fig. 3a and 3b). Loss in DNA integrity was observed with increase in ageing from 3 day of accelerated ageing more over decrease in DNA quantity was observed in aged seeds. Prolonged ageing up to 12 days further showed fragmentation of DNA.

\section{Discussion}

Ageing is a common phenomenon in all the living entities and as a result with increase in ageing progressive decline in all the vital events occur culminating to death at the end.

An elevated level of moisture content islethal to cells. In the present study with an increase in ageing period there was a concurrent rise in seed moisturecontent suggesting that greater sensitivity of longevity to the accelerated ageing time duration (Jain et al., 2006; Neelesh et al., 2011). The decrease in germination and increase in abnormal seedlings, dead seeds by accelerated aging may be a result of progressive loss of seed viability and vigor, which was evident in the results of this study (Jain et al., 2006). These observations that showed a decline in seed vigour were in accordance with earlier works on Artiplexcordobensis (Aiazzi et al., 1996) and soybean (Filho et al., 2001).

In the present findings all the ageing treatments resulted in membrane damage as evident from higher solute leakage in aged seeds. The loss was more pronounced in 3, 6, 9, 12 days of ageing which was higher over unaged seeds. Estimation of electrical conductivity of seed leachate was considered as a promising parameter in seed quality studies (Bewely and Black, 1994). The outer and inner membranes appeared as potential targets for desiccation and ageing injuries in seeds, seed ageing may cause activity alteration of low plasma membrane ATPase activity (Bardel et al., 2002).

Further in our investigations impairment in synthesis of enzymes was also noticed. Due to ageing decline in dehydrogenase activity. Many enzymes remain active after all viability lost, however the dehydrogenases are one group of enzymes that were shown to be directly related with loss of viability (Pandey, 1989). Reduction of 2,3,5-triphenyl -tetrazolium chloride or bromide to red coluredformazan by dehydrogenase enzymes is taken as an indication of living tissue, as ageing increases the activity of dehydrogenase is reduced. Ageing induced deterioration increases the extent of protein oxidation thus inducing the loss of function of all properties of proteins and enzymes (Loycrajjou and Dominique, 2008).

The effect of seed ageing on quantity and quality of DNA was further studied in the present investigations. There is good correlation between viability loss and chromosome damage in seeds, over a fairlywide range of temperatures and moisture content (Roberts, 1972). It is important to realize that such abnormalities represent gross damage to the DNA, and only when a critical proportion of aberrant dividing cells occur will root growth ceases with subsequent seedling death. Early observation showed that the filtrate from 
non-viable embryos contained more soluble nucleotides and less intact DNA than did prepared from viable embryos(Osborne,1983), the random cleavage of DNA as a result of DNAse activity had occurred in the dry seed. Inactivation of a DNAse inhibitor appeared to have taken place during prolonged seed storage, which was proposed as a major factor in the deterioration of the seeds. In our results also loss in DNA integrity was observed with increase in ageing from 3 days of accelerated ageing more over decrease in DNA quantity was observed in aged seeds. Similar results were reported in rye seeds where in decrease in total DNA content with decrease in seed viability was observed (Osborne, 1980). The breakdown products showed lowered absorbance (Gosh and Chaudhari, 1984). The molecular lesions associated with loss of viability (Osborne et al., 1974).

Integrity of macromolecules such as DNA may not be maintained during seed ageing and cleavage of DNA molecules to lower molecular weight fragments occurs without loss of DNA, by virtue of their larger size, susceptible to shear. Prolonged ageing up to 12 days further showed fragmentation of DNA. As seeds lost viability during ageing, DNA was gradually degraded into internucleosomal fragments, resulting in "DNA laddering". Nucleolytic events such as DNA laddering are known characteristic of programmed cell death (PCD).(Iise et al., 2011). Seed deterioration at the DNA level pointed out that chromosomal aberration, point mutations, and decreased activity of DNA repair enzymes are some of the major events occurring during the process of aging in seeds (Roberts, 1973; Murata et al., 1981; Roos, 1988; Gutierrez et al., 1993; McDonald, 1999).

The process of ageing in seeds involves deterioration of many systems with in the tissues. As it has been found in many other species, with time the tissues become leakier and thus results into membrane damage, enzyme inactivation. In addition to the physiological changes there is a considerable evidence to show that chromosomal damage and genetic mutation occurs in storage.

\section{References}

[1] Aiazzi, M. T., Arguell, J. A., Perezo, A., and Guzman, C. A., 1996. Deferioration in Artiplexcordobensis (GandogeretSuckert) seed: Natural and accelerated ageing. Seed Sci. Technol., 25:147-155.

[2] Bardel, J., Louwagie, M., Jaquinod, M., and Bourguignon, J., 2002. A survey of plant mitochondria proteome in relation with development. Proteomics, 2:880-898.

[3] Bewely, J. D., and Black, M., 1994. Seeds: Physiology of development and germination, pp.445-447, New York.

[4] Brockelhurst, P. A., and Fraser, R. S. S., 1980. Ribosomal RNA integrity and rate of seed germination.Planta, 148:417-421.

[5] Bushell. M., Stoneley, M., Sarnow, P., and Willis, A. E. 2004. Translation inhibition during the induction of apoptosis: RNA or protein degradation?.Biochem. Soc. T., 32:606-610.

[6] Doyle, J. J., and Doyle, J. L., 1990. Isolation of plant DNA from fresh tissue. Focus, 12: 13-15.

[7] Faria, J. M. R., Buitink, J., Van Lammeren, A. A. M., and Hilhorst, H. W. M., 2005. Changes in DNA and microtubules during loss and re-establishment of desiccation tolerance in germinating Medicagotruncatula seeds. J. Exp. Bot., 56:2119-2130.

[8] Filho JM, November ADC, Champma HMCP (2001) Accelerated ageing and controlled deterioration seed vigour tests for soybean. SciAgric 58:421-426.

[9] Gosh, B., and Chaudhari, M. M., 1984. Ribonucleic acid breakdown and loss of protein synthetic capacity with loss of viability of rice embryos. Seed Science and Technology, 12: 561-575.

[10] Gutierrez, G., Cruz, F., Moreno, J., Gonzalez-Hernandez, V. A., and Vazquez Ramos, J. M., 1993. Natural and artificial seed ageing in maize: germination and DNA synthesis. Seed Sci. Res., 3: 279-285.

[11] Hoeberichts, F. A., and Woltering, E. J., 2003. Multiple mediators of plant programmed cell death: interplay of conserved cell death mechanisms and plant-specific regulators. Bioessays, 25:47-57.

[12] Iise, K., Hongying, C., and Hugh, W., 2011. Inter-nucleosomal DNA fragmentation and loss of RNA integrity during seed ageing. Plant Growth Regul., 63: 63-72.

[13] ISTA, 1993. International rules for seed testing. Seed Sci. Technol., 21: 1-288

[14] ISTA, 2010. International rules for seed testing. Pp 27-42.

[15] Jain, N., Koopar, R., Saxena, S., 2006. Effect Accelerated Ageing on Seed of Radish (Raphanussativu L.). Asian Journal of Plant Sciences, 5(3):461-464.

[16] Jatoi, S. A., M. Afzal, S. Nasim, and Anwar, R., 2004. Seed deterioration study in pea using accelerated ageing techniques. Pak. J. Bioi. Sciences, 4: 1490-1494.

[17] Khan, A. M., Khan, H., Khan, R., and Aziz, A., 2007. Vigor tests used to rank seed lot quality and predict field emergence in wheat. Am. J. Plant Physiol., 2: 311-317.

[18] Kranner, I., Birtic, S., Anderson, K. M., and Pritchard, H. W., 2006. Glutathione half-cell reduction potential: A universal stress marker and modulator of programmed cell death? Free Radical Bio Med, 40:2155-2165.

[19] LoicRajjou, Manuel Duval, Karine Gallardo, Julie Catusse, Julia Bally, Claudette Job and Dominique Job, 2012. Annu. Rev. Plant Biol., 63:507-533.

[20] Malik, A. R., and Shamet, G. S., 2009. Storage of Pinusgerardiana seeds: Biochemical changes and its applicability as vigour test. Res. J. Seed Sci., 2: 48-55.

[21] Murata, M., Roos, E. E., and Tsuchiya, T., 1981. Chromosome damage induced b artificial seed ageing in barley. I. Germinability and frequency of aberrant anaphases at first mitosis. Can. J. Genet.Cytol ., 23:267-280.

[22] NeeleshKapoor, ArvindArya, MohdAsifSiddiqui, Hirdesh Kumar and Asad Amir, 2011.Physiological and biochemical changes during seed deterioration in aged seeds of Rice (Oryza sativa L.). American Journal of Plant Physiology, 6(1): 28-35.

[23] Osborne, D. J., 2000. Hazards of a germinating seed: Available water and the maintenance of genomic integrity. Israel J. Plant Sci., 48: 173-179.

[24] Osborne, D. J., Roberts, B. E., Payne, P. I., and Sen, S., 1974. Protein synthesi and viability in rye embryos.In Mechanisms of regulation of plant growth. Plant Physiology, 12: 805-812.

[25] Osborne, D. J., 1980. Senescence in seeds.Senescence in plants, pp., 13-37, CRC press, Boca Raton. 
[26] Pandey, D. K., 1989. Ageing of French bean seeds at ambient temperatures in relation to vigor and viability. Seed Sci. \& Technol., 10:81-102.

27] Perl, M., Luria, I., and Gelmond, H., 1978. Biochemical changes in sorghum seeds affected by accelerated ageing. J. Expt. Bot., 29: 497-501.

[28] Roberts, E. H., 1973. Loss of seed viability: chromosomal and genetic aspects. Seed Sci. \& Technol., 1: 515-527.

[29] Roberts, E. H., 1972. Cytological, genetical, metabolical changes associated with loss of viability. Viability in seeds, pp., 253-306, chapman and hall, London.

[30] Roos, E. E., 1988. Genetic changes in a collection over time. Hortic. Sci., 23: 86-90

[31] Sen, S., and Osborne, D. J., 1974. Germination of rye embryos following hydration-dehydration treatments-enhancement of protein and RNA — synthesis and earlier induction of DNA replication. J. Exp. Bot., 25:1010-1019.

[32] Sen, S., and Osborne, D. J., 1977. Decline in ribonucleic acid and protein synthesis with loss of viability during the early hours of imbibition of rye (Secalecereale L.) embryos.Biochem J., 166:33-38.

[33] Sundararaj, N., Nagaraju, S., Venkataraman, M. N., and Jaganath, M. K., 1972. Design and analysis of field experiments, University of Agricultural Sciences, Bangalore, pp165.

[34] Tekrony, D. M., 1993. Accelerated ageing test. J. Seed Technol., 17: 110-120.

[35] Thompson, S., Bryant, J. A., and Brockelhurst, P. A., 1987. Changes in levels and integrity of ribosomal RNA during seed maturation and germination in carrot (Daucuscarota L.). J. Exp. Bot., 38: 1343-1350.

[36] Tuteja, N., Singh, M. B., Misra, M. K., Bhalla, P. L., and Tuteja, R., 2001. Molecular mechanisms of DNA damage and repair: Progress in plants. Crit. Rev. Biochem. Mol. Biol., 36:337-397.

[37] Woltz, J. M., and Tekrony, D. M., 2001.Accelerated ageing test for corn seed. J. Seed Technol., 23: 21-34.

Table1. Seed moisture content and germination as influenced by temperature, relative humidity and ageing in maize.

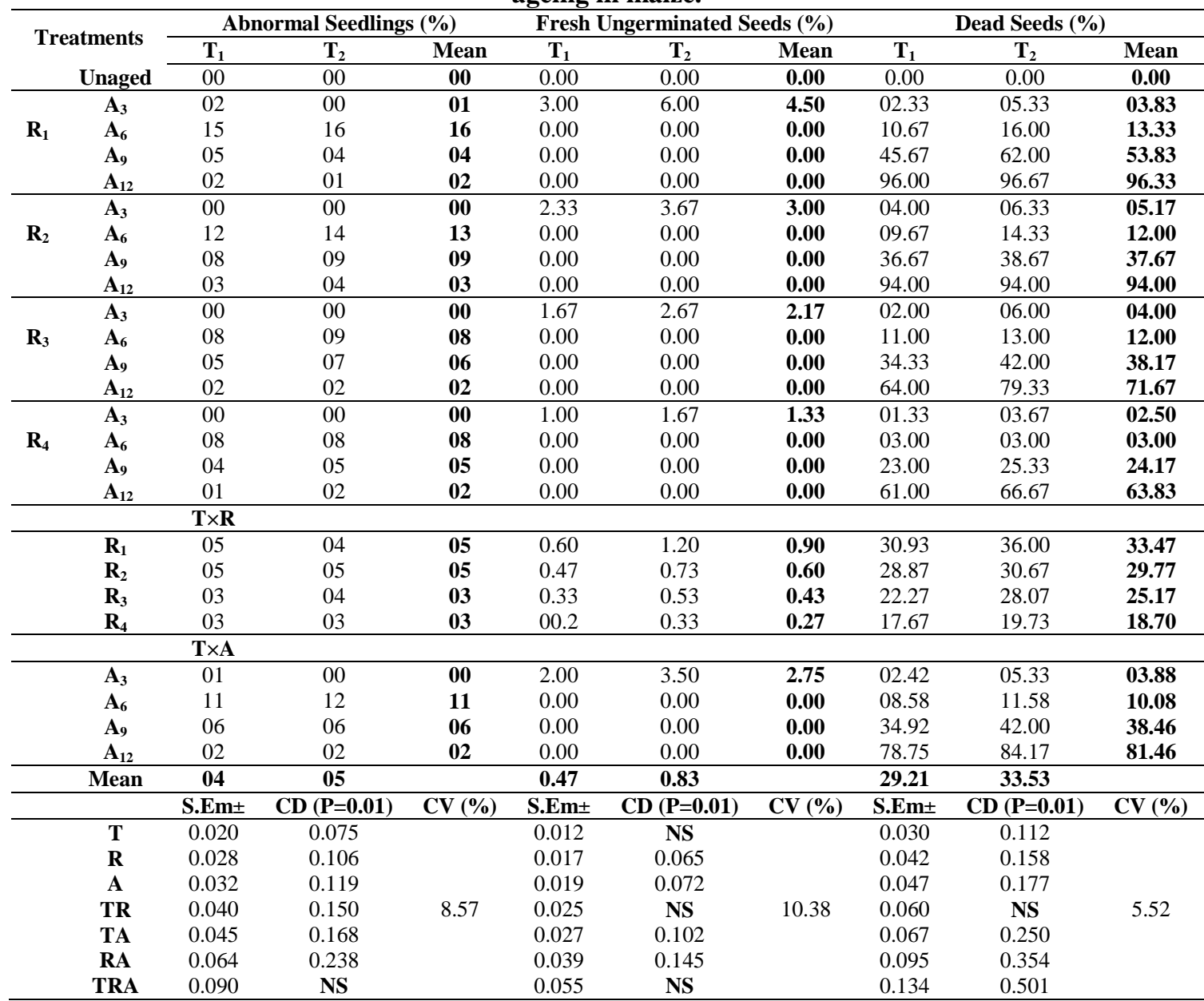

Temperatures $\left({ }^{\circ} \mathrm{C}\right)$

$\mathrm{T}_{1}: \mathrm{T}^{\circ} \mathrm{C}$

$\mathbf{T}_{2}: 42^{\circ} \mathrm{C}$

\begin{tabular}{lll}
\multicolumn{3}{l}{ Relative humidity } \\
$\mathbf{R}_{\mathbf{1}}$ & $:$ & 100 \\
$\mathbf{R}_{\mathbf{2}}$ & $:$ & 95 \\
$\mathbf{R}_{\mathbf{3}}$ & $:$ & 90 \\
$\mathbf{R}_{\mathbf{4}}$ & $:$ & 85
\end{tabular}

\section{Ageing periods}

$\mathbf{A}_{3}: 3$ days

A $\quad: 6$ days

A $\quad: \quad 9 \quad$ days 


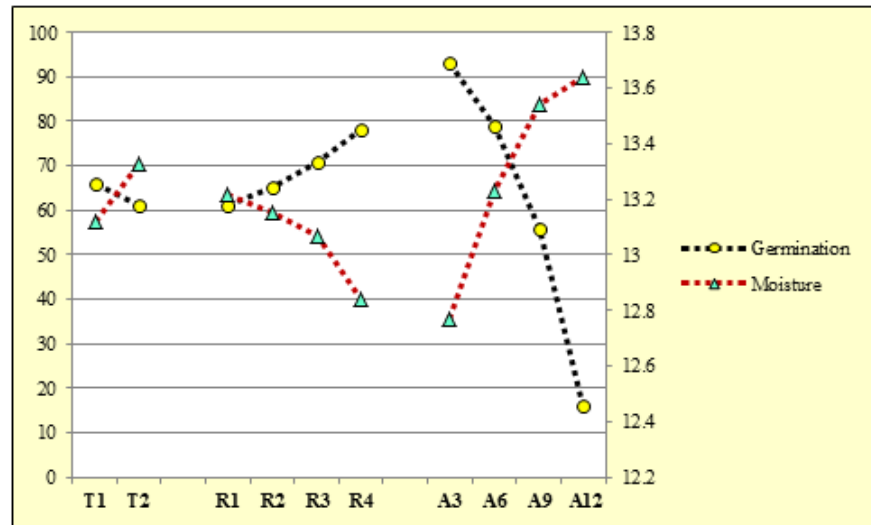

Figure 1. Seed moisture content and germination percentage as influenced by temperature, relative humidity and ageing period in maize

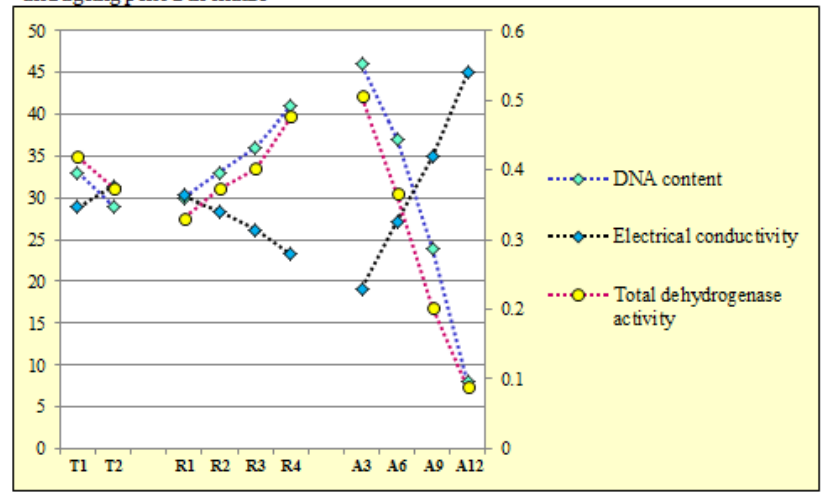

Figure 2.DNA content, Electrical conductivity and total dehydrogenase activity as influenced by temperature, relative humidity and ageing period in maize

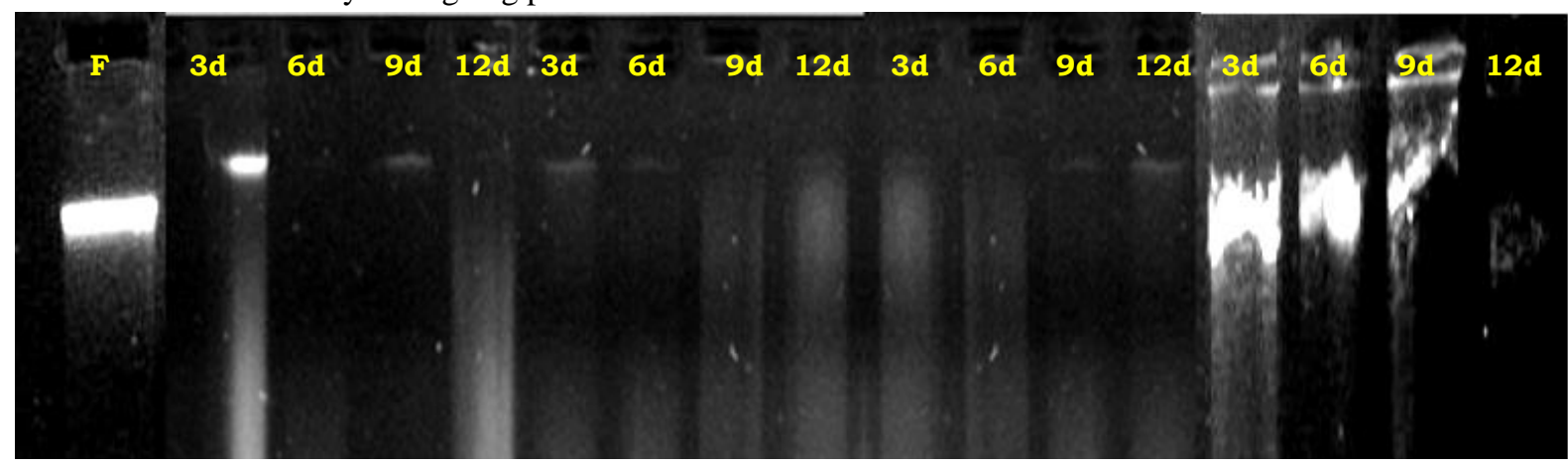

Figure 3a.DNA integrity in as influenced by accelerated ageing at a temperature of $42^{\circ} \mathrm{C}$ with different relative humidity levels

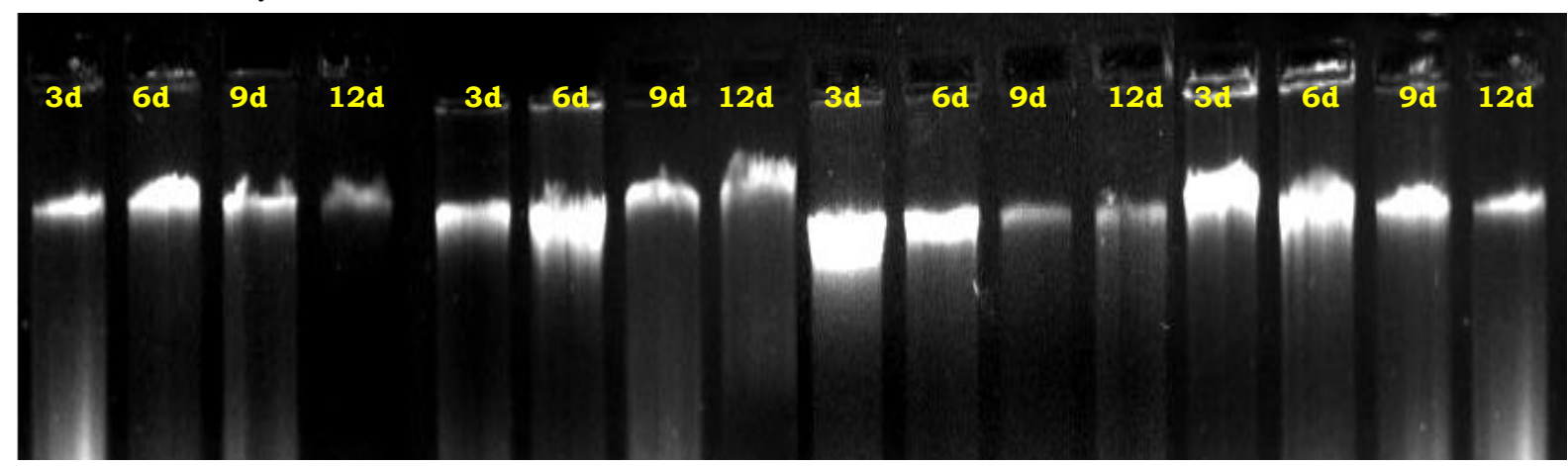

Figure 3b. DNA integrity in as influenced by accelerated ageing at a temperature of $40^{\circ} \mathrm{C}$ with different relative humidity levels

Figure 3.Representative electrophorograms of DNA of accelerated ageing 